\title{
PEMBAGIAN HAND SANITIZER PADA PEDAGANG TAKJIL DALAM MASA \\ PANDEMI COVID 19 DI LINGKUNGAN KELURAHAN LALOEHA KECAMATAN KOLAKA KABUPATEN KOLAKA
}

\section{THE DISTRIBUTION OF HAND SANITIZER ON THE TAKJIL TRADERS AT THE COVID 19 PANDEMIC IN THE LALOEHA URBAN VILLAGE, KOLAKA SUB- DISTRICT, KOLAKA REGENCY}

Abd. Gani Baeda ${ }^{1)^{*}}$, Bangu( ${ }^{2)}$, Risqi Wahyu Susanti ${ }^{3)}$, Tukatman ${ }^{4)}$, Heriviyatno Julika Siagian' Grace Tedy Tulak $^{6}$, Ekawati Saputri ${ }^{7)}$

\footnotetext{
${ }^{1)}$ Prodi DIII Keperawatan, Fakultas Sains dan Teknologi, Universitas Sembilanbelas November Kolaka email: Abganbaeda@gmail.com

${ }^{2)}$ Prodi DIII Keperawatan, Fakultas Sains dan Teknologi, Universitas Sembilanbelas November Kolaka email: abangakper@gmail.com

${ }^{3)}$ Prodi DIII Keperawatan, Fakultas Sains dan Teknologi, Universitas Sembilanbelas November Kolaka email: risqi_wahyu@usn.ac.id

${ }^{4)}$ Prodi DIII Keperawatan, Fakultas Sains dan Teknologi, Universitas Sembilanbelas November Kolaka email: nstukatman@gmail.com

${ }^{5)}$ Prodi DIII Keperawatan, Fakultas Sains dan Teknologi, Universitas Sembilanbelas November Kolaka email: heriviyatno.j.siagian@gmail.com

${ }^{6)}$ Prodi DIII Keperawatan, Fakultas Sains dan Teknologi, Universitas Sembilanbelas November Kolaka email: gracelavianni@gmail.com

${ }^{7)}$ Prodi DIII Keperawatan, Fakultas Sains dan Teknologi, Universitas Sembilanbelas November Kolaka email: ekawatisaputri@ gmail.com
}

\section{ABSTRAK}

Indonesia merupakan salah satu negara yang mengalami pandemi covid-19 dengan jumlah Positif 10.118, Sembuh 1.522, dan meninggal 792 orang. Semua provinsi di Indonesia mengalami pandemi ini, khususnya di Sulawesi Tenggara terdapat 62 kasus konfirmasi positif, 10 orang sembuh dan 2 meninggal dunia dan khusus Kabupaten kolaka terdapat 1 orang kasus konfirmasi positif. Tujuan kegiatan pengabdian adalah untuk memutus mata rantai penyebaran covid 19 melalui penggunaan hand sanitizer di Kelurahan Laloeha, Kec. Kolaka, Kab. Kolaka. Pengabdian ini merupakan tindakan preventif penularan covid 19 masa pandemi dengan pembagian hand sanitizer kepada 30 pedagang takjil di Jl Pintu Selatan Kelurahan Laloeha Kec Kolaka, Kab Kolaka. Hasil pengabdian ini adalah tingginya minat para pedagang mendengarkan penjelasan tim pengabdian dan menerima hand sanitizer yang dibagikan.

Kata kunci : Pembagian hand sanitizer, Pedagang takjil, Covid 19

\section{ABSTRACT}

Indonesia is one of the countries that experienced a covid-19 pandemic with a positive number of 10,118, 1,522 healed, and 792 people died. All provinces in Indonesia experienced this pandemic, especially in Southeast Sulawesi, there were 62 positive confirmation cases, 10 people recovered and 2 died and specifically Kolaka regency there was 1 positive confirmation case. The purpose of the community service activity is to break the chain of distribution of covid 19 through the use of a hand sanitizer in the Urban Village of Laloeha, Kolaka sub-district, Kolaka regency. This service is a preventive measure of transmission covid 19 at pandemic period with the distribution of hand sanitizers to 30 takjil traders on Jl Pintu Selata, urban village of Laloeha, Kolaka subdistrict, Kolaka Regency. The result of this dedication was the high interest of the traders listening to the devotion team's explanation and receiving the hand sanitizer that was distributed.

Keywords: Distribution of hand sanitizer, Traders of takjil, Covid 19 
PENDAHULUAN

Saat ini dunia sedang mengalami pandemi covid-19, data yang diperoleh pada tanggal 30 April 2020 menurut WHO tercatat 3.059.642 kasus konfirmasi positif dan 211.028 kematian yang tersebar pada 213 negara [6]. Indonesia merupakan salah satu negara yang mengalami pandemi covid19 dengan jumlah Positif 10.118, Sembuh 1.522, dan meninggal 792. Semua provinsi di Indonesia mengalami pandemi ini, khususnya di Sulawesi Tenggara terdapat 62 kasus konfirmasi positif, 10 orang sembuh dan 2 meninggal dunia dan khusus Kabupaten kolaka terdapat 1 orang kasus konfirmasi positif [2].

Coronavirus Disease 2019 (COVID-19) adalah penyakit jenis baru yang belum pernah diidentifikasi sebelumnya pada manusia. Virus penyebab COVID-19 ini dinamakan Sars-CoV-2. Virus corona adalah zoonosis (ditularkan antara hewan dan manusia). Penelitian menyebutkan bahwa SARS ditransmisikan dari kucing luwak (civet cats) ke manusia dan MERS dari unta ke manusia. Adapun, hewan yang menjadi sumber penularan COVID-19 ini sampai saat ini masih belum diketahui [3].

Melihat cepatnya penyebaran covid-19 di dunia dengan penularan antara manusia ke manusia yang cepat telah dikonfirmasi secara luas dan belum ada antivirus yang ditemukan maupun vaksinasinya [4]. Menurut Kemenkes diantara langkahlangkah pencegahan yang paling efektif di masyarakat meliputi: (1) melakukan kebersihan tangan menggunakan hand sanitizer jika tangan tidak terlihat kotor atau cuci tangan dengan sabun jika tangan terlihat kotor; (2) menghindari menyentuh mata, hidung dan mulut; (3) terapkan etika batuk atau bersin dengan menutup hidung dan mulut dengan lengan atas bagian dalam atau tisu, lalu buanglah tisu ke tempat sampah; (4) pakailah masker medis jika memiliki gejala pernapasan dan melakukan kebersihan tangan setelah membuang masker; dan (5) menjaga jarak (minimal 1 m) dari orang yang mengalami gejala gangguan pernapasan [3].

Pada keyataannya menurut survei tim pengabdian di Kabupaten Kolaka Sulawesi Tenggara, tidak semua masyarakat bisa mematuhi pencegahan Covid 19 terutama masyarakat yang memiliki penghasilan harian seperti pedagang dan yang ramai saat ini adalah pedagang takjil yang sangat dibutuhkan setiap hari oleh masyarakat terutama saat bulan ramadhan ini. Sehingga dengan tuntutan tersebut masyarakat akan saling berinteraksi satu sama lain yang tidak bisa dihindari.

Berdasarkan hal tersebut, tim akan melakukan pengabdian masyarakat di pandemi covid 19 ini dengan membagikan hand sanitizer pada pedagang takjil mengingat salah satu langkah pencegahan covid 19 adalah dengan melakukan cuci tangan dengan sabun atau dengan hand sanitizer. Apa lagi di masa pandemi ini, 
hand sanitizer sangat langkah dan jika ada memiliki harga yang cukup mahal sehingga sangat sulit dijangkau oleh masyarakat ditambah harga yang lumayan mahal.

Adapun hand sanitizier yang dibagikan berbahan dasar adalah alkohol atau etanol. Etanol digunakan di seluruh dunia dalam fasilitas kesehatan untuk hand rubbing atau hand sanitizer atau pembersih tangan. Etanol pada $80 \%$ sangat efektif terhadap semua 21 virus yang dites dalam waktu 30 detik. Murine norovirus dan adenovirus tipe 5 biasanya dinonaktifkan oleh etanol antara $70 \%$ dan $90 \%$ dalam 30 detik sedangkan poliovirus tipe 1 sering ditemukan terlalu resisten kecuali untuk etanol pada $95 \%$ (semua virus uji EN 14476) [1].

Hand sanitizer dapat terbuat dengan hanya menggunakan bahan-bahan berikut dalam persiapan produk [5]:

1. (Pilih satu dari dua opsi) (1) Alkohol (etanol) yang tidak kurang dari 94,9\% etanol menurut volume; ATAU (2) Farmakope Amerika Serikat (kadar USP) Isopropyl Alkohol

2. Glycerin (gliserol) USP atau Food Chemical Codex (FCC) (juga dikenal sebagai "food grade")

3. Hidrogen peroksida

4. Air steril (mis., Dengan cara direbus, distilasi, atau proses lain yang menghasilkan air yang memenuhi spesifikasi untuk USP Air Murni). Air harus digunakan secepat mungkin setelah dibuat steril atau dimurnikan.
Pengabdian masyakat ini merupakan salah satu langkah preventif penularan covid 19 yaitu dengan pembagian hand sanitizer pada pedagang takjil yang sangat rentan tertular atau menularkan virus corona mengingat jenis virus baru ini bersifat asimptom atau tanpa gejala sehingga perlu dilakukan pemutusan mata rantai.

\section{METODE PELAKSANAAN KEGIATAN}

Metode yang akan digunakan pada kegiatan ini adalah tindakan preventif penularan covid 19 masa pandemi dengan pemberian hand sanitizier yang berbahan dasar alkohol $>75 \%$ yang dibagi ke dalam botol fliptop dengan isi $60 \mathrm{ml}$ perbotol pada pedagang takjil di jl. Pintu Selatan, Kel. Laloeha, Kec. Kolaka, Kab. Kolaka.

Kegiatan pengabdian ini dilaksanakan di Kel. Laloeha, Kec. Kolaka, Kab. Kolaka pada tanggal 11 Mei 2020. Sasaran pelaksanaan kegiatan pengabdian ini adalah berbagai elemen masyarakat yang rentan terkena penyakit covid-19 pada masa pandemi khususnya pedagang yang selalu berinteraksi dengan banyak pembeli di Jl. Pintu Selatan, Kel. Laloeha, Kec. Kolaka, Kab. Kolaka.

Alat dan bahan yang digunakan dalam kegiatan pengabdian ini adalah alkohol > $75 \%$ yang dimasukan kedalam botol fliptop ukuran $60 \mathrm{ml}$. Evaluasi yang akan digunakan pada kegiatan pengabdian ini adalah mengevaluasi penggunaan hand sanitizer pada pedagang takjil selama 
melayani pembeli setelah diberikan hand sanitizer serta melihat tanggapan pedagang takjil saat tim memberikan hand sanitizer.

\section{HASIL DAN PEMBAHASAN}

Pedagang takjil adalah salah satu dari pelaku usaha yang banyak berinteraksi dengan masyarakat di tengah pandemik Covid 19 tidak terkecuali di Jl. Pintu Selatan, Kel. Laloeha, Kec. Kolaka, Kab. Kolaka. Adanya interaksi ini, diharapkan pencegahan penularan Covid 19 dapat dimaksimalkan melalui cara jaga jarak (physical distancing), cuci tangan dan pemakaian hand sanitizer. Salah satu upaya yang dilakukan untuk pencegahan penularan Covid 19 dengan pembagian hand sanitizer pada pedagang takjil dimana ini merupakan bentuk kegiatan pengabdian masyarakat yang dilakukan oleh dosen Prodi DIII Keperawatan Fakultas Sains dan Teknologi Universitas Sembilanbelas November Kolaka.

Kegiatan ini sebagai upaya pencegahan dan memutus mata rantai penularan Covid 19 melalui pembagian hand sanitizer dilaksanakan pada tanggal 11 Mei 2020 bertempat di Jl. Pintu Selatan, Kel. Laloeha, Kec. Kolaka, Kab. Kolaka mulai pukul 15.00 WITA hingga selesai.

Adapun pelaksanaan pengabdian masyarakat yang berupa pembagian hand sanitizer kepada pedagang takjil adalah sebagai berikut:
1. Persiapan sebelum kegiatan

a. Mengurus ijin pelaksanaan melalui Ketua LP2M-PMP Universitas Sembilanbelas November Kolaka kemudian diberikan surat pengantar yang ditujukan ke Lurah Laloeha.

b. Pembuatan hand sanitizer berbahan alkohol $>75 \%$.

c. Pembuatan spanduk.

2. Pelaksanaan Kegiatan

Adapun pelaksanaan kegiatan pencegahan penularan Covid 19 melalui kegiatan pembagian hand sanitizer sebagai berikut:

a. Persiapan sasaran kegiatan

Sasaran kegiatan ini adalah pedagang yang menjual takjil di $\mathrm{Jl}$. Pintu Selatan Kelurahan Laloeha Kecamatan Kolaka sebanyak 30 orang.

b. Proses Kegiatan

Sebelum pembagian hand sanitizer, tim pengabdian menjelaskan tujuan kegiatan dan manfaat yang dapat diperoleh dari pembagian hand sanitizer dalam rangka memutus rantai penularan covid 19. Setelah itu tim membagikan hand sanitizer kepada setiap pedagang yang menjual takjil di Jl Pintu Selatan Kelurahan Laloeha Kecamatan Kolaka. 


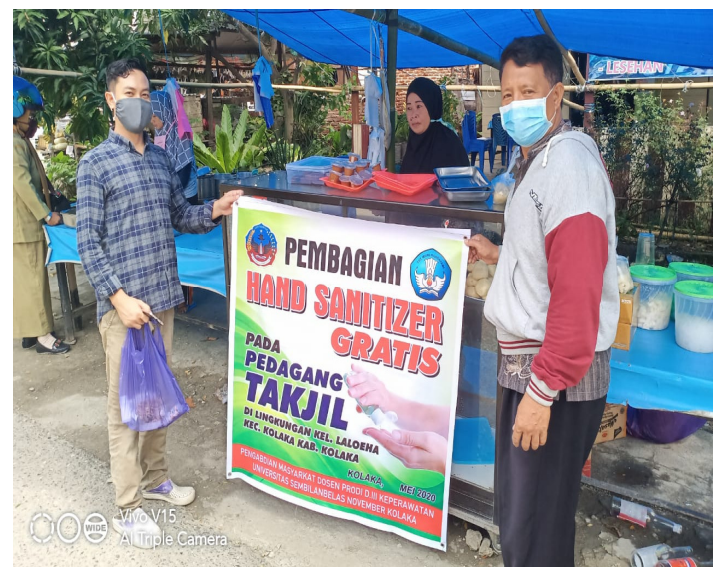

Gambar 1. Pembagian Hand sanitizer

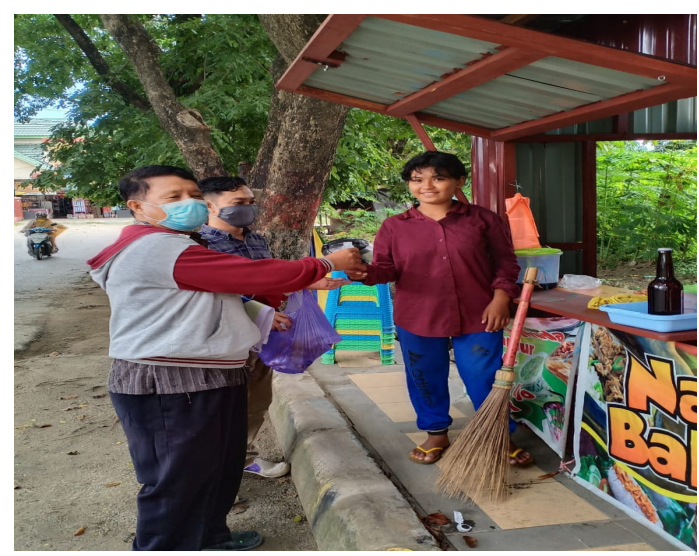

Gambar 2. Pembagian Hand sanitizer

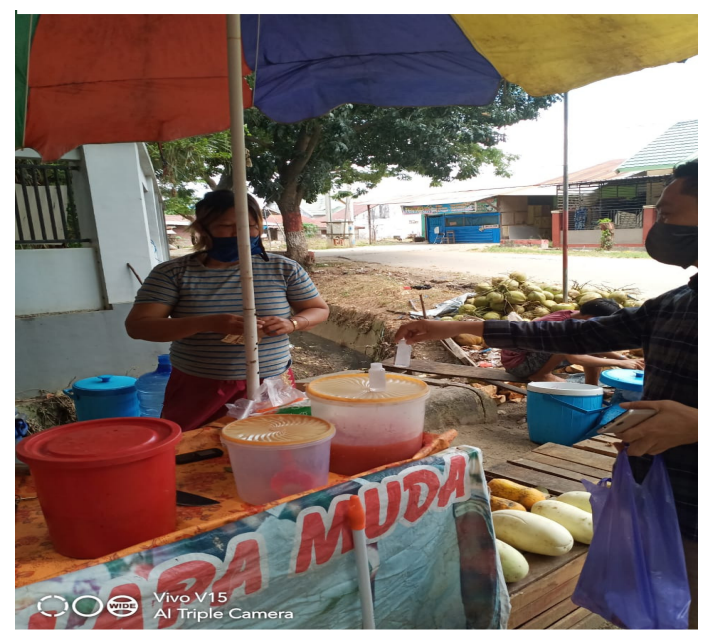

Gambar 3. Pembagian Hand sanitizer

3. Evaluasi

Hasil evaluasi dari kegiatan pengabdian ini adalah :

a. Tingginya minat para pedagang mendengarkan penjelasan tim pengabdian dan menerima hand sanitizer yang dibagikan

b. Para pedagang menggunakan hand sanitizer sebelum dan sesudah melayani pelanggan yang membeli dagangan mereka.

4. Hambatan dan Kendala

Hambatan dan kendala yang dihadapi dalam persiapan kegiatan ini yakni terbatasnya persediaan alat dan bahan yang digunakan untuk pembuatan hand sanitizer di daerah kolaka sehingga sebagian alat yang digunakan harus dipesan dari luar kota.

5. Kekuatan

Adapun kekuatan dalam pelaksanaan penyuluhan ini adalah dukungan dari pihak universitas dan pemerintah Kelurahan Laloeha yang memberikan ijin melaksanakan kegiatan pengabdian ini dalam masa pandemi Covid 19.

\section{KESIMPULAN}

Kegiatan pengabdian masyarakat untuk pencegahan penularan Covid 19 melalui pembagian hand sanitizer dengan sasaran pedagang takjil sebanyak 30 orang. Sebelum pembagian hand sanitizer tim pengabdian menjelaskan tujuan kegiatan dan manfaat yang dapat diperoleh dari pembagian hand sanitizer dalam rangka memutus rantai penularan Covid 19. Diharapkan kegiatan ini dapat mencegah penularan Covid 19 antar pedagang dan pembeli saat melakukan interaksi jual beli. 


\section{SARAN}

Saran dari hasil kegiatan ini adalah diharapkan kegiatan ini dapat dilanjutkan dengan memperluas sasaran kegiatan seluruh pedagang di seluruh wilayah Kecamatan Kolaka dengan melibatkan stakeholder. Hal ini bertujuan untuk memutuskan mata rantai penularan Covid 19 di wilayah Kecamatan Kolaka tidak terkecuali kabupaten Kolaka.

\section{UCAPAN TERIMAKASIH}

Ucapan terima kasih pada seluruh pihak yang terkait pada kegiatan pengabdian masyarakat ini diantaranya: Lurah Laloeha, Kepala LP2M-PMP Universitas Sembilanbelas November Kolaka dan pihak lainnya.

\section{REFERENSI}

[1] Kampf, G. (2018). Efficacy of Ethanol Against Viruses in Hand Disinfection. Journal of Hospital Infection, 98(4), 331-338.

[2] Kemenkes RI. (2020a). Data Sebaran. Retrieved April 30, 2020, from kemkes.go.id
[3] Kemenkes RI. (2020b). Pedoman Kesiapsiagaan Menghadapi Coronavirus Disease (COVID-19). Retrieved from https://www.kemkes.go.id/resources/d ownload/info-terkini/COVID-19

dokumen resmi/2 Pedoman Pencegahan dan Pengendalian Coronavirus Disease (COVID-19).pdf

[4] Shereen, M. A., Khan, S., Kazmi, A., Bashir, N., \& Siddique, R. (2020). COVID-19 Infection: Origin, Transmission, and Characteristics of Human Coronaviruses. Journal of Advanced Research, 24, 91-98.

[5] U.S. Department of Health and Human Services. (2020). Temporary Policy for Preparation of Certain AlcoholBased Hand Sanitizer Products During the Public Health Emergency ( COVID-19 ) Guidance for Industry Temporary Policy for Preparation of Certain Alcohol-Based Hand Sanitizer Products During the Public Health. Contains Nondinding Recommendations, (March). Retrieved from https://www.fda.gov/media/136118/do wnload

[6] WHO. (2020). Coronavirus disease (COVID-19) outbreak situation. Retrieved April 30, 2020, from https://www.who.int/emergencies/dise ases/novel-coronavirus-2019 